University of Washington Tacoma

UW Tacoma Digital Commons

Business Publications

Milgard School of Business

$3-2007$

\title{
High Noon On the Western Range: A Property Rights Analysis of the Johnson County War
}

Doug Wills

University of Washington - Tacoma Campus, dtwills@uw.edu

Randy McFerrin

New Mexico State University - Main Campus

Follow this and additional works at: https://digitalcommons.tacoma.uw.edu/business_pub

Part of the Economic History Commons, Property Law and Real Estate Commons, and the United States History Commons

\section{Recommended Citation}

Wills, Doug and McFerrin, Randy, "High Noon On the Western Range: A Property Rights Analysis of the Johnson County War" (2007). Business Publications. 2.

https://digitalcommons.tacoma.uw.edu/business_pub/2

This Article is brought to you for free and open access by the Milgard School of Business at UW Tacoma Digital Commons. It has been accepted for inclusion in Business Publications by an authorized administrator of UW Tacoma Digital Commons. 


\title{
High Noon on the Western Range: A Property Rights Analysis of the Johnson County War
}

\section{RANDY MCFERRIN AND DOUGLAS WILLS}

\begin{abstract}
Wyoming's Johnson County War of 1892 is the historical basis of later popular depictions of the West as violent, and it influenced the development of Wyoming. Many see this era as the end of the open range system and the ascendancy of stock ranching and farming. Popular depiction argues that the event was an act of vigilantism of large foreign-owned firms against small individual settlers. We argue that the war was a conflict of property rights systems and use a model developed by Alston, Libecap, and Mueller to explain why violence broke out in Johnson County in 1892.
\end{abstract}

\begin{abstract}
Richer (the Rancher): We made this country. Found it and we made it . . Made a safe range out of this. Some us died doin' it. We made it. Then people move in who never held a rawhide through the old days. Fenced off my range. Fenced me off from water. Some of them like you paw ditches, and take out irrigation water, and so the creek runs dry sometimes, and I got to move my stock because of it. And you say we have no rights to the range.
\end{abstract}

Stark (the Homesteader): You talk about rights. You think you got the right to say that nobody else has got any. Well, that ain't the way the government looks at it.

Shane [Paramount Pictures, 1953]

$\mathrm{I}$

$\mathrm{n}$ the spring of 1892 , several prominent range cattle businessmen, all members of the Wyoming Stock Growers' Association (WSGA), organized a small armed militia. The purpose of the militia, as the organizers later claimed, was to clear northern Wyoming of rustlers - it was simply to protect the private property of the range cattle firms. It was on this basis that the WSGA recruited gunmen throughout the U.S. West and mobilized in Cheyenne. However, the organizers had broader goals than simply to impose vigilante justice on rustlers. They wanted to overthrow the newly emerging political structure in the county, take charge of the courthouse, and, as such, the legal process. With the rise in

The Journal of Economic History, Vol. 67, No. 1 (March 2007). (C) The Economic History Association. All rights reserved. ISSN 0022-0507.

Randy McFerrin is Assistant Professor of Economics, College of Business and Economics, New Mexico State University, Las Cruces, NM 88003. E-mail: mcferrin@nmsu.edu. Douglas Wills is Associate Professor of Finance; Milgard School of Business; University of Washington, Tacoma; Tacoma, WA 98402. E-mail: dtwills@u.washington.edu. 
homesteader settlement and subsequent decrease in political influence of the cattle industry, especially with the financial downturn of the industry in the late $1880 \mathrm{~s}$, these businessmen felt that their rights were inadequately protected. They had all but given up trying to convict individuals of stealing their property, usually cattle, and decided instead to reestablish their influence via armed conflict.

On 6 April 1892 the militia began its 120-mile march to Buffalo, the seat of Johnson County. While in route, the militia came across some alleged rustlers at a ranch 50 miles south of Buffalo. After a heated debate, the militia decided to deal with the "rustlers" before continuing on to their intended destination. Expected to last but a few hours, it evolved into a disastrous daylong ordeal. This delay cost the militia the advantage of surprise as the news of the "invading" militia along with its intent reached Buffalo. ${ }^{1}$ Red Angus, the county sheriff, quickly organized a counter force of over 200 men who rode out to meet and neutralize the militia. Upon hearing of the approaching force, the militia fortified themselves at a local ranch house. When news of the siege leaked out, Wyoming's governor successfully petitioned President Harding to send government troops to rescue the besieged militia. ${ }^{2}$ All of the militia members were arrested and held first at Fort McKinney and then in Cheyenne. While all were eventually freed, many of the ranches owned by the organizers were ransacked and their property taken. ${ }^{3}$

Known today as the Johnson County War of 1892, these events form the historic basis for many of the popular film depictions of the U.S. West, starting with the original Virginian (1914) to Shane (1953) to Heaven's Gate (1980). Furthermore, historians argue that they were important because they altered the political structure in Wyoming, influencing the fall elections. ${ }^{4}$ Moreover, D. F. Baber argues in the preface to his book that the War is important because it is "... the conflict which marks the dividing line between the old West, under the rule of the big cattle kings, and the new West of the pioneer homesteader." The state Republican Party was strongly associated with the interests of the range cattle industry and, as such, paid a political price for the "war."

\footnotetext{
${ }^{1}$ While the operation was kept secret to gain the advantage of surprise, the leaders did not intend to remain anonymous. Reporters were included in the militia entourage (Larson, History, p. 274).

${ }^{2}$ The local ranch was the TA ranch located 13 miles southwest of Fort McKinney. The initial counter force arrived at the ranch on 11 April, and government troops arrived on the morning of 13 April. A total of two days transpired between the arrival of the counter force and the arrival of government troops.

${ }^{3}$ Larson, History, p. 279

${ }^{4}$ Ibid., pp. 284-92. The war prompted the merging of the Democratic and Populists parties in Wyoming. After the election, Democrats carried all but Laramie County.

${ }_{5}^{5}$ Baber, Longest Rope, preface.
} 
Essentially, the war was a dispute over land, and it is common to depict all such land disputes in the west as resolved violently rather than peacefully through negotiation. On the other hand, recent work by economists has shown that the West may not have been as violent as popularly believed. ${ }^{6}$ Moreover, Terry Anderson and Fred McChesney argue that what violence did occur resulted from the calculations of rational, utility-maximizing individuals. ${ }^{7}$ They demonstrate that not all land conflicts result in violence. To understand the resolution of land disputes, they lay out the necessary conditions for individuals to resort to violence rather than negotiation. This article follows that approach to analyze the Johnson County War as a conflict between two rational antagonists in a land dispute: ranchers, defined as large range cattle firms, and homesteaders, defined as farmers and small cattle ranchers.

The fundamental conflict was control of the public domain. Over several decades, ranchers had developed use rights to the range. However, in the late $1880 \mathrm{~s}$, homesteaders began to migrate onto the public domain claiming portions of the range under various federal land acts, the most notable being the Homestead Act of 1862 . However, this migration rarely lead to the type of organized violence seen in the Johnson County War. To identify the key parameters affecting whether the conflict ends in violence, the article uses a variation of a model developed to analyze land conflicts in the Brazilian Amazon. ${ }^{8}$ In this model, ranchers must decide on the level of effort to expend in resisting invasion or evicting homesteaders once occupancy occurs. Simultaneously, homesteaders must choose the level of effort to expend on invading an occupied range or resisting eviction. We argue that the probability of violence increases when efforts for eviction and resistance increases. As such, the article explains why this violence took place in Johnson County and in 1892 .

\section{CATTLE, LAND, AND PROPERTY RIGHTS}

The range cattle industry dominated business in Wyoming during the $1880 \mathrm{~s}$. For the time, cattle concerns were large enterprises often financed by foreign capital. Production methods were land intensive based upon usufruct rights in land and fee simple title to cattle. Invested capital consisted almost entirely of cattle with only a small proportion of land held in fee simple. Moreover, the practice of grazing cattle on the range until ready for market exhibits substantial economies of

\footnotetext{
${ }^{6}$ Anderson and Hill, Not So Wild, Wild West.

${ }^{7}$ Anderson and McChesney, "Raid."

${ }^{8}$ Alston, Libecap, and Mueller, "Land Reform Policies."
} 
scale. ${ }^{9}$ To take advantage of this, cattlemen grazed cattle communally on the public range and conducted joint roundups. This organizational structure with its mix of public and private ownership to the inputs of production was the direct outcome of federal land laws.

Market imperfections such as minimum price floors and acreage constraints along with bureaucratic impediments prevented market transactions from solving the land ownership issue. However, in the early development of the industry these were not binding constraints given the initial nonscarcity of land. Range use allocations occurred by the common law doctrine of prior appropriation whereby individuals set up operations by claiming a range and publicly stating their intent. Once such proclamation read

I, the undersigned, do hereby notify the public that I claim the valley, branching off the Glendive Creek, four miles east of Allard, and extending to its source on the South side of the Northern Pacific Railroad as a stock range. - Chas. S. Johnson. ${ }^{10}$

For the most part, an informal network of codes and customs of the west evolved to protect use rights. These protections were credible enough such that use rights obtained market value and were fully transferable. ${ }^{11}$

By the mid-1880s, conditions changed such that informal arrangements became less effective in protecting rights. Homesteaders, with the promise of legal title to land, came into this existing system of use rights and began establishing claims on ranges already extensively used by cattlemen. As competition increased, cattlemen found it economically viable to devote additional resources to alter the existing institutional framework governing range use. Early on, cattlemen lobbied Congress to alter federal land laws to align better with the conditions of the arid west where a cow required from 20 to 40 acres. If successful, this would allow market transactions to prevent this type of competition. Yet, their efforts failed in persuading Congress. Gary Libecap argues that Congress and the General Land Office intentionally obstructed western cattlemen's efforts to gain legal recognition of their established use rights or to alter existing land policies. ${ }^{12}$ Federal land policy favored

\footnotetext{
${ }^{9}$ See Eaton, "Wyoming Stock Growers Association,” p. 136.

${ }^{10}$ Osgood, Day, p. 183.

${ }^{11}$ See Anderson and Hill, "Evolution"; and Ellickson, Order, for a discussion of informal networks. In Wyoming, a set of rights sold for "something over $\$ 200,000$," and one cattle company reported a value of $\$ 85,000$ for range rights: Dennen, From Common to Private Property, p. 110. Fred Hesse obtained the use of 50,000 acres in exchange for debts from Morton Frewen: Sandoz, Cattlemen, p. 333. This suggests that early arrangements were effective in protecting range rights.

${ }^{12}$ Libecap, Locking Up the Range.
} 
small claimants over cattlemen in developing political constituencies. In large part, this reflected the desire to populate territories with smallscale farmers for admission as new states rather than establishing a monopoly over the public ranges controlled by a relatively few cattlemen. ${ }^{13}$ In contrast, the evolution of federal mining and preemption laws did formally recognize established use rights, whereas the evolution of federal land laws never recognized cattlemen's use rights. This failure to alter existing land laws effectively rendered cattlemen squatters on the public domain. ${ }^{14}$

Compounding this was the passage of a congressional resolution in 1868 that represented a shift in federal land policy from one of revenue generation to territorial settlement. This effectively ended cash sales and prohibited cattlemen from securing private title to enough land through this avenue. ${ }^{15}$ Moreover, acreage limitations under the various land acts fell far short of the minimum requirement for western conditions. Cattlemen could only claim a total of 1,120 acres. The Preemption Act of 1841 and the Desert Land Act of 1877 allowed the purchase of 160 and 640 acres at a price of $\$ 1.25$ per acre respectively. Under the Homestead Act of 1862 and the Timber Culture Act of 1873, an individual could claim an additional 320 acres at a zero price per acre. However, the price floor of $\$ 1.25$ per acre under the acts wildly overpriced western land. ${ }^{16}$

Yet the inability to secure legal title did not prevent cattlemen from amending their informal institutions in response to increased competition. ${ }^{17}$ In this context, any such alteration must lower the costs of identifying ownership of range cattle, of gathering range cattle for branding and marketing purposes, of protecting ownership rights to cattle in distant markets and of controlling access to the open range. ${ }^{18}$ The Wyoming Stock Growers Association (WSGA), the most successful of all

\footnotetext{
${ }^{13}$ Clawson, Uncle Sam's Acres, p. 62. Libecap argues that the primary reason for the obstruction was that the Land Office's budget depended on case loads processed. To increase their budget, the Land Office had to increase workload. This favored the small land claimant over the land-intensive rancher.

${ }^{14}$ This is not unlike the situation in much of South America as noted by Desoto, Mystery.

${ }^{15}$ Hibbard, History, p. 111. Gates, "Homestead Law," argues that cash sale of land continued after 1868 using commutation of homestead entries under preemption, state land grants, Indian lands, and other Federal lands. However, this does not appear to have been a viable option in Wyoming. Only small fraction of the public domain was transferable under these entries.

${ }^{16}$ Dennen estimates the open market value of land at less than ten cents per acre. Dennen, From Common to Private Property, p. 9.

${ }^{17}$ See Anderson and Hill, "Evolution" and "Race"; and Anderson and Grewell, "Property Rights Solutions," for a complete discussion of the evolution of institutions on the western range.

${ }^{18}$ Eaton, "Wyoming Stock Growers Association," p. 133. These issues are the result of the communal grazing on public land. In particular, the issue of open access and the tragedy of the commons that could result from a failure to control range use.
} 
stock associations in the U.S. West, emerged in this respect as the primary institution to regulate Wyoming ranges and dominated the Territorial Legislature. In 1882, 55 percent of the legislators were stockmen with at least one-third being members of the WSGA, while the legislative committee concerning the stock industry had an association member as its chair between 1875 and $1890 .^{19}$

The WSGA, through legislative acts and internal activities, created an institutional framework to govern the Wyoming range. Acts between 1869 and 1884 vested control over registering of brands with the WSGA, and the Maverick Law addressed ownership of unbranded range cattle (mavericks) and the negative externalities associated with individual roundups. ${ }^{20}$ This law, passed in 1884 , established a communal roundup under the legal control of the WSGA. The association had the authority to determine the timing of and participation in a communal roundup along with the branding of mavericks. Internally, the WSGA created an inspection and detective bureau funded primarily from the sale of mavericks to protect rights on the range and in distant markets. At its height, the bureau employed 22 inspectors and detectives and had an operating budget of $\$ 946,916 .^{21}$ Moreover, under the influence of the association, Wyoming evolved into a fence out state rather than fence in as under the common law. Cattlemen were liable for damages only if their cattle breached a lawful enclosure. This shifting of the liability made it costly for homesteaders to set up claims on the range given the initial high cost of traditional fencing materials.

By controlling participation in the annual roundup, the association controlled access to the range. Membership required the sponsorship of a current WSGA member and approval of the membership committee. The association was not shy about blacklisting or denying membership to individuals it considered of "bad character." This all but ensured that the individual could not participate in the roundup. All mavericks gathered during the roundup essentially became the property of the WSGA and any nonmember's cattle gathered were confis-

\footnotetext{
${ }^{19}$ See Jackson, "Wyoming Stock Growers' Association," for a full discussion of the political activities of the WSGA.

${ }^{20}$ See Wyoming Stock Growers Association. By-Laws, for a complete discussion of Wyoming Stock Laws. Communal roundups avoid excessive trampling of grass and overstressing cattle associated with individual roundups. However, communal grazing creates an incentive to brand cattle first. Once branded, a maverick becomes the property of the owner of the brand. Initially, the doctrine of presumptive ownership addressed this incentive by allocating mavericks under various rules such as proportional allotment. This agreement began to break down as the ranges became crowded. The maverick law attempted to overcame this by vesting the power to brand with the WSGA.

${ }^{21} 2005$ dollars. See Table 3.
} 
cated and sold at auction. ${ }^{22}$ The effective result of control over the roundup made it costly to operate a cattle firm on a range without being an association member.

By 1884 the WSGA controlled access to the open range through membership and the Maverick Law. However, during the later part of the decade, the principle competition for range use was small stock ranchers, sheepherders, and farmers known as "grangers." The largest granger community developed in Sheridan, Johnson, and Crook counties were due to geographical conditions. ${ }^{23}$ Farm operations in the northeast were smaller and devoted a larger proportion of farm acreage to traditional cereal crops compared to the statewide average. ${ }^{24}$ Farms in the southern portion of the state were larger and primarily used for winter hay for range cattle. This pattern of farm settlement supports Frank Canton's assertion that "I expect to have a very heavy race to run, as my opponent is a granger and that element has the majority in this county" when he ran for Johnson County Sheriff. ${ }^{25}$ By 1890 the pattern of settlement indicates a higher proportion of the population in the northeast being direct competitors to the open range system than in the south.

Beginning in the mid 1880 s, several changes occurred that began to unravel the institutional arrangement. The election of President Cleveland in 1884 and appointment of William Sparks as Commissioner of the General Land Office represented a shift in the federal government's support of homesteaders against ranchers. ${ }^{26}$ In addition, the winter of 1886/87 left many cattlemen bankrupt, and many quit the business altogether. Membership in the WSGA dropped from 349 to 183 in 1889. As range competition increased, the confiscation of nonmember's cattle became a serious issue and the Maverick Law came under increasing assault in the legislature. In 1891 the legislature repealed the law, representing a significant reduction in the association's ability to protect range rights and rights in cattle. Additionally, the territorial legislature divested the WSGA of direct control over the roundup when it transferred authority to a newly created Board of Livestock Commissioners.

\footnotetext{
${ }^{22}$ Owners of confiscated cattle could petition the WSGA for the remittance of the funds generated from their confiscated cattle. However, the WSGA controlled what evidence would be considered proof of ownership.

${ }^{23}$ Viable farming in the arid West required steady water flows for irrigation along with low construction costs of irrigation canals. Northeast Wyoming provided adequate summer water flow and the cost of constructing canals was lower than in the rest of Wyoming: U.S. Census Bureau. Report on Agriculture, pp. 248-54.

${ }^{24}$ This is evident in Table 5.

${ }^{25}$ Quoted in Larson, History, p. 188. Frank Canton was at one time a detective for the WSGA.

${ }^{26}$ Libecap, Locking Up the Range, p. 32.
} 
The sentiment at the time indicates that this shift of decision-making power led to increased cattle theft and mavericking. ${ }^{27}$

With respect to the illegal fencing question, the Justice Department handled early cases, but with limited success. ${ }^{28}$ However, the passage of the Illegal Inclosure Act in 1885 strengthened the government's ability to remove illegal inclosures. ${ }^{29}$ In United States v. Bradford, the court using the Illegal Inclosure Act ruled that individuals under the pretense of inclosing their own land could not inclose public land as well. ${ }^{30}$

By the end of the 1880s, the WSGA had lost substantial control over access to the range and protection of cattle from theft began to breakdown at an increasing pace. ${ }^{31}$ Indeed, the financial difficulties of the WSGA after the winter storms of $1886 / 87$ forced the disbanding of the detective and inspection bureau in 1888. The final straw was the formation of the Northern Wyoming Farmers and Stock Growers Association in 1892. This association represented an alliance of small stock growers and grangers that was in direct competition to the WSGA. They announced a separate roundup one month prior to the legal roundup. This struck at the heart of WSGA power and was the event that triggered the efforts to organize a militia setting the stage for the aforementioned Johnson County War of 1892.

\section{A MODEL FOR ANALYZING CONFLICT}

Not all competition over land use ends in violent confrontation. Indeed, the history of Wyoming is a case in point. Except for isolated incidences of lynching and vigilantism, the vast majority of Wyoming and the U.S. West peacefully transferred from the public domain into private ownership. ${ }^{32}$ What, then, lead to the Johnson County War of 1892 ? To set out these conditions, we use a model developed to analyze conflict in the Brazilian Amazon by Lee Alston, Libecap, and Bernardo Mueller. ${ }^{33}$

${ }^{27}$ Larson, History, p. 269.

${ }^{28}$ Ibid., p. 179. Cattlemen began to construct fences in an effort to exclude grangers from their ranges. In the process, cattlemen inclosed substantial portions of the public domain as well. See Larson, History, p. 32, for a full discussion of illegal fencing.

${ }^{29}$ 48th Cong. Ch. 149; 23 Stat. 321.

${ }^{30} 8$ Utah 173,30 P 433.

${ }^{31}$ Larson, History, p. 271. Smith, War, pp. 116-17.

${ }^{32}$ See Anderson and Hill, Not So Wild, Wild West.

${ }^{33}$ Alston, Libecap, Mueller, "Land Reform Policies." In Brazil, land reforms set up the potential for conflict between individuals who held legal title to the land and landless peasants. Many times this conflict resulted in violence; their model lays out the necessary conditions for an increase in the probability of violence. However, the Homestead Act encouraged occupation of land held by the Federal government that was largely unoccupied. In Brazil, the level of violent confrontation was much greater than in the American West. The level of confrontation resulting 
In contrast to Brazil, Wyoming ranchers occupied large tracts of public land and homesteaders engaged in efforts to invade and occupy this land. To simplify the analysis, we assume the antagonists attempt to maximize land value and only two outcomes are possible. Either a rancher maintains the use of the land and the homesteader loses the use of the land or homesteaders invade and successfully resist eviction, in which case the rancher loses the use of the land. ${ }^{34}$ In either case, neither receives compensation for their lost use of the land. Therefore, the problem facing both ranchers and homesteaders is to choose the optimal level of effort to expend on obtaining use of the disputed land. Let $v$ represent the level of activity by ranchers to maintain the use of land. These efforts include activities designed to resist initial occupancy and efforts to evict once occupancy occurs. ${ }^{35}$ Let $s$ denote the level of effort expended by homesteaders to occupy the range and resist cattlemen's efforts to evict them from the range. If both $v$ and $s$ increase simultaneously, then the probability of resolving land disputes through violent means increases. The important task is to determine under what conditions both $v$ and $s$ increase simultaneously.

The probability that ranchers maintain the use of disputed land depends on the level of $v$ supplied, the level of support from state and local government (both legislative and judicial) $k$, and the relative population (ranchers to homesteaders), $n$. We write this probability as:

$$
\beta(v, k, n) \text { where } \beta_{v}>0, \beta_{k}>0, \beta_{n}>0, \beta_{v v}<0, \beta_{k k}<0, \beta_{n n}<0
$$

Support from state and local government augments a rancher's ability to resist invasion and to evict homesteaders. ${ }^{36}$ During the early development of Wyoming, the territorial legislature was instrumental in developing its stock laws for the protection of a rancher's cattle and establishing entry barriers to the range. The Maverick Law was the primary stock law used by ranchers to control entry. Judicial support further

from the Homestead Act would not reach the level in Brazil until the migration of farmers encountered a system developed for the arid conditions of the West. However, we believe it appropriate to use a model developed to analyze a situation where violence was more common to analyze a situation where violence was less common as in the American West.

${ }^{34}$ These assumptions are equivalent to the Alston et al. model derived in their appendix. However, the homesteader has legal title to the land rather than the rancher as in the Alston model.

${ }^{35}$ This specification of $v$ is more general than Alston's specification in that efforts to protect cattlemen's use rights to land include resisting homesteader's efforts to occupy the range and evicting homesteaders once actual occupation occurred rather than simple eviction efforts.

${ }^{36}$ In our model $k$ is an exogenous parameter that either enhances or diminishes the efforts of ranchers in protecting their legal rights to property such as cattle. In the Brazilian context, the role of the courts is the protection of the owners' legal rights to the land itself. 
strengthened property rights in cattle. Local courts could either enforce the stock laws such as the Maverick Law or choose to look the other way. Any increase in local governmental support increases the probability of maintaining the use of the land by ranchers.

The distribution of $n$ affects the expected outcome of a violent confrontation. At the two extremes of the distribution, the outcome is certain. If $n$ is sufficiently high, then homesteaders are not likely to waste resources fighting eviction given that the expected outcome favors ranchers. On the other hand, at sufficiently low $n$ ranchers would not waste resources resisting and evicting homesteaders given that the expected outcome favors homesteaders. Between these two points, however, the outcome of a dispute is uncertain and the expected outcome favors neither ranchers nor homesteaders. It is in this range that violent confrontation is likely. ${ }^{37}$ In other words, when the relative population is neither too "high" nor "low" the outcome from using violence to settle disputes is uncertain.

What is more, the probability that the federal government through either the Department of the Interior, the Justice Department, or the military will intervene on behalf of homesteaders also affects the ability of ranchers to maintain the use of disputed land. This is a function of three variables; the level of $s$ supplied by homesteaders; the level of security of a rancher's property rights, $p$; and the political support for the principles behind the Homestead Act itself, $g .{ }^{38}$ The probability of the federal government intervening against ranchers is given by equation 2 .

$$
\theta(s, p, g) \text {, where } \theta_{s}>0, \theta_{p}<0, \theta_{g}>0, \theta_{s s}<0, \theta_{p p}<0, \theta_{g g}<0
$$

Combining equations 1 and 2, one can write the ranchers' expected value function from maintaining the use of the range as

$$
\begin{aligned}
& E V_{R}=\beta(v, k, n) L+(1-\beta(v, k, n)[1-\theta(s, P, G)] L-C(v), \\
& \text { where } C v>0
\end{aligned}
$$

${ }^{37}$ This analysis is similar to that of Allen ("Homesteading") where he argued that relative population is a critical component of disputes between whites and Indians in settling the West. He argued that the U.S. government used the Homestead Act as a method of rushing settlers into a territory, increasing the relative population to a point where the federal government could bypass the zone of violence. In our context, we argue that this zone of violence existed to the greatest extent in the northeast portion of the state in 1892 .

${ }^{38}$ In Brazilian context, $g$ represents the attitude of the Land Authority towards land reform in supporting the efforts of squatters in their attempt to expropriate privately owned land. In our case, it is the attitude of the Department of the Interior towards the settler's efforts in invading and resisting eviction from land to which they may hold legal rights. In our model, $p$ has a different interpretation. It is the strength of extralegal institutions that arose on the plains in protecting a rancher's use rights. The most notable institution for our study was The Wyoming Stock Growers Association. 
The first term represents the expected returns from a successful eviction, and the second term is the expected loss if eviction efforts fail. $L$ is the value of land and $C(v)$ is the cost function for supplying units of $v$, which is increasing in $v$ with $C_{v v}>0$. The goal of the rancher is to choose the level of $v$ that maximizes equation 3. Differentiating the objective function with respect to $v$ yields the rancher's first order condition given by equation 4 .

$$
\left.\beta_{v} \theta(s, p, G)\right] L-C(v)=0
$$

Equation 4 represents the marginal benefit and cost of supplying units of $v . \theta(s, p, g)] L$ is the expected loss avoided by the rancher, and $\beta_{v}$ is the marginal increase in the probability of evicting the homesteader with respect to increases in effort. The rancher balances this gain against the marginal cost, $C_{v}$.

Simultaneously the homesteader will choose the level of effort, $s$ that maximizes the following expected value function

$$
\begin{aligned}
& \left.E V_{H}=(1-\beta(v, k, n)) \theta(s, p, \mathrm{~g})\right] L-C(s), \\
& \text { where } C_{s}>0 \text { and } C_{s s}>0
\end{aligned}
$$

The first term in the equation represents the probability of a successfully occupying the range, and the second term is the probability of intervention by the federal government. Together with the value of the land $L$, this term represents the expected payoff to the homesteader from occupying the range and resisting eviction by ranchers. The last term is the cost function from the perspective of the homesteader. This function is increasing in $s$. The goal of the homesteader is to choose the optimal level of $s$ that maximizes equation 5. Differentiating this objective function with respect to $s$ yields equation 6 , which is the first order condition for the homesteader.

$$
[(1-\beta(v, k, n))] \theta_{s} L-C_{s}=0
$$

A marginal increase in the probability of the federal government intervening, $\theta_{s}$, times the value of the land gives the marginal benefit of another unit of $s . C_{s}$ is the marginal cost of another unit of homesteader effort. The homesteader balances the gain from the use of the land against the cost of invading and resisting eviction efforts.

As in the Alston et al. model, the joint solution of the individual maximization problems produce a Nash equilibrium where the level of efforts $v^{*}$ and $s^{*}$ are such that both equation 4 and equation 6 hold 
TABLE 1

IMPACTS OF CHANGES IN EXOGENOUS VARIABLES ON THE OPTIMAL LEVEL OF $V$ AND $S$

\begin{tabular}{lccccc}
\hline \hline & Impact on Reaction Curve & \multicolumn{2}{c}{ Impact on } \\
\hline & Rancher & Homesteader & $\mathrm{v}^{*}$ & $\mathrm{~s}^{*}$ \\
& + & - & & - & - \\
Increase in property rights, $p$ & + & + & + & + \\
Increase in land value, $L$ & - & - & - & - \\
Increase in cost, $C$ & + & + & + & + \\
Increase in support from federal government, $g$ & + & - & - & - \\
Increase in support from local government, $k$ & + & - & & - & - \\
Increase in relative population, $n$ & + & & & &
\end{tabular}

Note: See equations 1-6.

simultaneously. Differentiating the first order conditions with respect to each parameter of the model and solving for the underlying derivatives yields the reaction function for each player in the land dispute. Establishing their slope is critical in understanding how each player responds to changes in the other's level of effort, holding the exogenous parameters constant. It is straightforward to demonstrate that the slope of the homesteader's reaction function is negative with respect to changes in $v$ whereas the rancher's is positive with respect to changes in $s$ for any given set of exogenous parameters. ${ }^{39}$ In other words, ranchers will respond to increases in $s$ by supplying more $v$ but homesteaders will supply less $s$ in response to increases in $v$, all else constant.

Critical for analyzing the Johnson County War is how the optimal levels of $s$ and $v$ responds to changes in the parameters $n, k, p, g, L$, and $C$. To ascertain these effects, we conducted a comparative static analysis of each of the exogenous parameters. Table 1 contains the results from this analysis. ${ }^{40}$ Changes in exogenous parameters shift each player's reaction function. As a result, the change in either $s$ or $v$ will be unambiguous for one but ambiguous for the other. For example, an increase in $n$ shifts the rancher's function to the right and the homesteader's function to the left as in Figure 1. Homesteaders respond by unambiguously supplying less $s$, but the change in $v$ is ambiguous. The source of the ambiguity is that two effects operate on the rancher, the direct and the indirect effect. The direct effect is the shift of the reaction

\footnotetext{
${ }^{39}$ For a derivation of the slopes of each reaction function, see Alston et al., "Land Reform Policies."

${ }^{40}$ These results are identical to the results of the Alston model except that we deviate from the Alston model by explicitly modeling the probability of an eviction as a function of the proportion of ranchers to homesteaders. For a derivation of the results with respect to $n$, see the Appendix. For the other parameters, see Alston et al., "Land Reform Policies."
} 


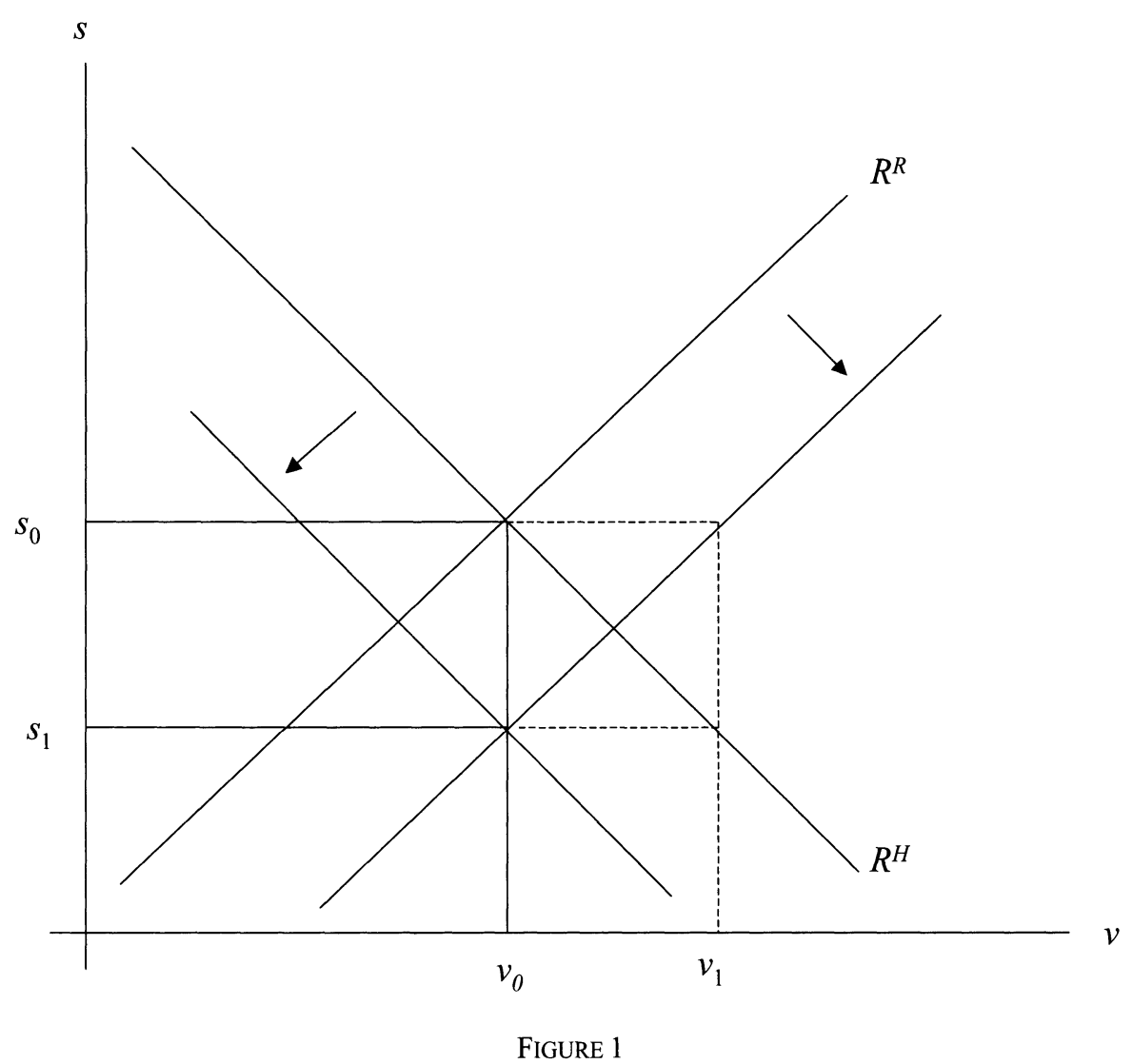

THE EFFECTS OF AN INCREASE IN $N$

Note: Terms are defined in Table 1.

function that increases $v$ for any given level of $s$. However, $s$ unambiguously falls. Given the positive slope of the rancher's reaction function, they respond to a decrease in $s$ by reducing the supply of $v$, which is the indirect effect. ${ }^{41}$ As a result, the optimal level of $v$ depends on the relative shifts of the reaction curves. If the homesteader's shift dominates the rancher's, then the impact on both $v$ and $s$ is negative. In other words, an increase in the relative population makes the outcome of violence more certain, which lowers the likelihood of violence and vice versa.

To make definitive statements on the optimal level of $v^{*}$ and $s^{*}$, the relative elasticity of the reaction curves with respect to changes in each exogenous variable must be known. Clearly, the determination of which party is more responsive is an empirical issue. In the absence of data and

${ }^{41}$ This result of a direct and indirect effect is identical to direct and strategic effects in the Alston model. 
in order to determine unambiguous effects from changes in parameters we assume that homesteaders are always more sensitive to changes in parameters than ranchers. In other words, homesteader reaction curves are always more elastic than those for ranchers. ${ }^{42}$ The simple rationale for this assumption is given that the homestead was, in most cases, a homesteader's entire capital whereas it was a small fraction for a rancher then homesteaders will be more sensitive to changes in parameters.

Table 1 lays out the necessary conditions for an increase in the probability that individuals will resort to violence in resolving land disputes. For this to occur, the supply of $v$ and $s$ must increase simultaneously. Both ranchers and homesteaders will increase their supply of $v$ and $s$ if the value of land or the support from the federal government increases. Furthermore, they will increase their supply of $v$ and $s$ if property rights protection, cost of supplying effort, support from local government, or relative population decrease. We will argue that all six parameters changed in a manner that increased the probability that ranchers and homesteaders would resort to violence in settling their dispute over land in Johnson County.

\section{EVIDENCE}

In the following section, we lay out the shifts for each exogenous variable in the model and their implication for the Johnson County war of 1892 .

\section{L, Land Values}

The value of land for agricultural purposes is a function of three variables: the value of the output produced, cost of transportation to markets, and the marginal productivity of land. In this context, output values increased, transportation costs fell, and the marginal productivity of Wyoming land increased relative to surrounding territories. We constructed three indexes to demonstrate the increase in the value of land with 1880 the base year. The first is a weighted average of the value of the yield per acre for primary cereal crops, and the second and third measure changes in cattle values and transportation costs respectively. ${ }^{43}$ Figure 2 presents the indexes for 1880 through 1900. Several trends are worth noting. By 1891, cattle prices experienced a 29.16 percent decline

\footnotetext{
${ }^{42}$ This assumption plays the same role as the Alston et al. assumption that the direct effect is always greater than the strategic effect.

${ }^{43}$ Acreages of corn, oats, and wheat accounted for 97 percent of the cereal grains harvested in Wyoming in 1890 . Oats accounted for 67 percent of the total cereal grains harvested. Transportation costs are average freight charges per ton-mile.
} 


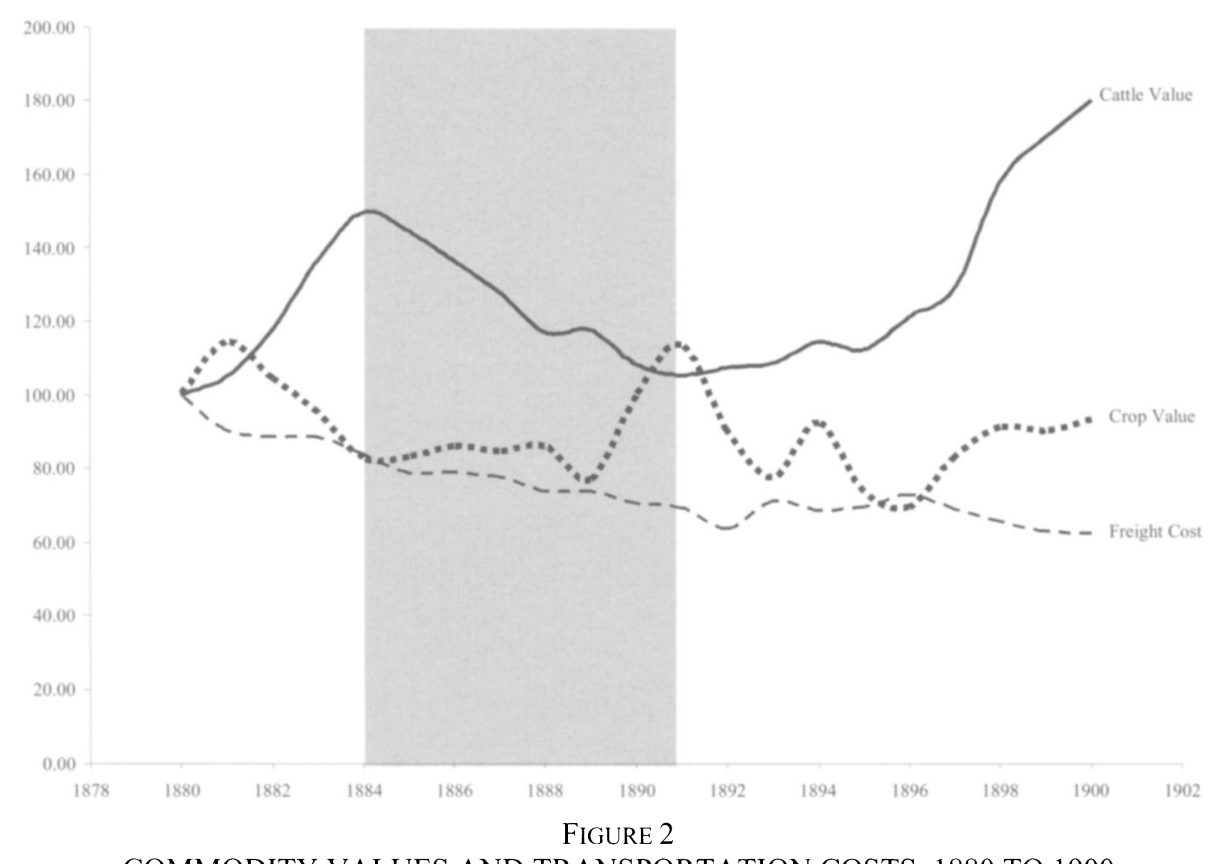

COMMODITY VALUES AND TRANSPORTATION COSTS, 1880 TO 1900

Source: Statistical Abstract of United States, 1900.

from their peak in 1884 . Crop prices increased 37.7 percent, and transportation costs fell by 37.45 percent between 1884 and 1891. As indicated in Figure 2, changing output values and transportation costs increased the rate of return to Wyoming lands.

With respect to the marginal productivity of land in Wyoming, the important factor was the marginal productivity of lands in Nebraska and Kansas. By 1892, the combined population of Kansas and Nebraska approached 2.5 million with some 20 million acres contained in homesteads. As population increased, the marginal productivity of land in these states decreased. In turn, the marginal productivity of land in Wyoming increased relative to lands in Kansas and Nebraska. This change in relative marginal productivity increased the value of land in Wyoming.

Increasing land values shifted the reaction functions for both ranchers and homesteaders to the right. The impact on the optimal level of $v$ is unambiguously positive. Ranchers respond to these changes by increasing their efforts at resisting and evicting homesteaders given the payoff to such activities increased. On the other hand, the impact on $s$ is ambiguous. The payoff to homesteaders increased, but the optimal level of $v$ also increased. As long as the shift of the homesteader's function 
TABLE 2

REAL COST OF BARBED WIRE FENCING, 1874-1897

\begin{tabular}{lc}
\hline \hline Year & Cost per 100 Pounds \\
\hline 1874 & 308.17 \\
1880 & 198.02 \\
1885 & 86.21 \\
1890 & 70.81 \\
1897 & 39.88 \\
Change 1874-1897 (percent) & -87 \\
\hline
\end{tabular}

Source: Webb, Great Plains, p. 310.

dominates the rancher's shift, then the impact on the optimal levels of $v$ and $s$ will be positive increasing the probability of violence.

\section{C, Per Unit Cost of Supplying Effort}

One obstacle facing both homesteaders and ranchers in maintaining the use of land was the cost of fencing western plains. Traditional materials such as stone and wood were scarce, raising their cost substantially. The invention of a low cost method of producing barbed wire in 1874 significantly lowered the cost of constructing fences on the plains. In turn, this lowered the cost for both ranchers and homesteaders in asserting and defending their claims to disputed land. Without this invention, the rate of return to farming in the West was much lower due to a farmer's inability to protect his crops from damage due to trespassing cattle, given that Wyoming was a fence-out state. Simultaneously, ranchers could protect their existing ranges from intruding homesteaders.

Table 2 presents the trend in the cost of barbed wire fencing from 1874 to 1897 . The real cost of barbed wire fencing decreased 87 percent over this period. This shifted homesteaders' reaction curve to the right increasing the optimal level of $s$. They could now move onto the arid plains of Wyoming, stake a homestead claim, and protect their investment from damage caused by range cattle at a reasonably low cost, thereby increasing the rate of return to a Wyoming farm. Ranchers respond to increases in $s$ by sliding up their reaction curve given its positive slope. The drop in fence costs increased the optimal supply of $s$ and $v$ leading to an increase in the probability of violence.

\section{p, Property Rights}

The primary institution through which open range ranchers protected their investment in cattle and range rights was the WSGA that provided 
TABLE 3

DETECTIVES, INSPECTORS AND REAL EXPENDITURES, 1880-1894

\begin{tabular}{cccc}
\hline \hline Year & Detectives and Inspectors & Detective Bureau $^{\text {a }}$ & Inspections $^{\text {a }}$ \\
\hline 1880 & 3 & & \\
1881 & 3 & & \\
1882 & 7 & 67,965 & 126,968 \\
1883 & 13 & 439,827 & 259,732 \\
1884 & 12 & 519,053 & 278,466 \\
1885 & 22 & 312,041 & 427,863 \\
1886 & 14 & 355,223 & 484,187 \\
1887 & 13 & 348,097 & 287,156 \\
1888 & 10 & & \\
1889 & 9 & & 206,688 \\
1890 & 8 & & \\
1891 & 8 & & 222,355 \\
1892 & 8 & & \\
1893 & 7 & & \\
1894 & 7 & & \\
\end{tabular}

${ }^{a}$ Blank cells indicate that the data were not available for that year.

Source: Financial Statements of the Wyoming Stock Growers Association

essential inspection and detective services. Table 3 provides data on the number of inspectors and detectives and real expenditures for these services. Data are most complete for the number employed with a high of 22 in 1885 followed by a 68 percent decline by 1894 . Expenditures for detective services pertain to the years 1883 to 1888 . Real expenditures for detective services peaked in 1885 and declined by 32 percent by 1888 when the WSGA disbanded the bureau. Furthermore, between 1882 and 1894 real expenditures for inspection services declined 54 percent.

As is evident in Table 3, expenditures for enforcement activities steadily increased until 1886. In the aftermath of the winter storm of 1886 , most large cattle outfits were bankrupt. The WSGA found itself in similar financial shape and by 1887 could no longer finance the detective bureau due to declining membership and revenues. While expenditures for inspection services continued, they never approached their high of 1886 . These changes represent a decrease in the parameter $P$ causing an outward shift of both the homesteader's and rancher's reaction functions. As a result, the optimal levels of both $v$ and $s$ increased leading to an increase in the probability of using violence to resolve land disputes.

\section{g, Federal Government Support}

The primary change in the probability of federal government intervention in the dispute between homesteaders and ranchers was the passage of the 1885 Illegal Inclosure Act. This act was the primary legal 
vehicle used by the federal government to prevent cattlemen from inclosing the public domain. Further supporting the homesteaders were the election of President Cleveland and the appointment of Secretary Sparks. After this point, the federal government became more actively involved in the dispute between homesteaders and ranchers, and the 1885 act gave the federal government a legal method to intervene. This shifted the reaction functions of both ranchers and homesteaders to the right. Again, as long as the shift of the homesteader's function dominates the ranchers, the optimal level of both $s$ and $v$ will increase. As a result, the probability that homesteaders and ranchers resort to violence will increase.

\section{k, Local Government Support}

With respect to protection from the courts, the ability of cattlemen to obtain convictions in local courts for theft of cattle was important. Evidence from Johnson County court records indicates that in 1885, of the nine cases of theft brought to trial, five resulted in convictions. However, in 1889 , of the 14 cases brought to trial, none led to a conviction, and thereafter no cases of theft appear in the court records. ${ }^{44}$ This indicates a substantial decline in the ability of cattlemen to obtain convictions for stock theft.

With declining conviction rates and legislative changes such as the repeal of the Maverick Law and creation of the Board of Livestock Commissioners, support of local government $k$, fell. As a result, the reaction curve for homesteaders shifted out while the function for ranchers shifted in. Unambiguously, the optimal amount of $s$ supplied by homesteaders increased, but the effect on ranchers is ambiguous. With less support, the probability that homesteaders will resist eviction efforts increases. Ranchers initially respond to the fall in $k$ by reducing $v$, but the increase in $s$ induces them to supply more efforts at eviction. As long as the reaction curve of the homesteaders dominates the shift of the rancher's curve, the optimal value of $v$ will increase as well. As a result, both $s$ and $v$ increased leading to an increase in the probability of violence in settling land disputes.

\section{n, Relative Population}

To construct a measure of relative populations by county, one would like to have data on individuals engaged in ranching and farming, however,

${ }^{44}$ Smith, War, pp. 116-17. 
TABLE 4

STATE LEVEL CHARACTERISTICS, 1890

\begin{tabular}{lccccc}
\hline \hline \multicolumn{1}{c}{ State } & $\begin{array}{c}\text { Number of } \\
\text { Farmers }^{\text {a }}\end{array}$ & $\begin{array}{c}\text { Number of } \\
\text { Cattlemen }^{\text {a }}\end{array}$ & $\begin{array}{c}\text { Percentage } \\
\text { Crop Land }\end{array}$ & $\begin{array}{c}\text { Actual } \\
\text { Relative } \\
\text { Population }\end{array}$ & $\begin{array}{c}\text { Predicted } \\
\text { Relative } \\
\text { Population }\end{array}$ \\
\hline Arizona & 2,172 & 2,712 & 1.75 & 1.25 & 1.25 \\
Colorado & 20,294 & 5,297 & 7.64 & 0.26 & 0.44 \\
Montana & 5,623 & 4,427 & 3.93 & 0.79 & 0.95 \\
Nevada & 1,643 & 1,949 & 0.93 & 1.19 & 1.36 \\
New Mexico & 10,256 & 6,832 & 7.82 & 0.67 & 0.41 \\
Utah & 12,340 & 2,418 & 9.28 & 0.20 & 0.21 \\
Wyoming & 2,571 & 4,147 & 1.19 & 1.61 & 1.33
\end{tabular}

${ }^{a}$ U.S. Census Bureau, 1890 Census, Statistics of Population, table 79, pp. 306-41, and Special Census Report, table 3, pp. 34-57.

these data exists only at the state level for Wyoming in 1890. To overcome this limitation, we constructed a prediction equation based upon state-level data using the percentage of farmland devoted to cereal crops such as corn, wheat, and oats for seven western states as the predictor. The presence of cereal crops is a strong indicator of a lower relative population. During this period, farmers grew cereal crops primarily for market sale and not as feed for cattle. We use the equation to predict a county's relative population. ${ }^{45}$ Table 4 contains state level characteristics used to develop the prediction equation. States with a high percentage of farmland devoted to cereal crop production also had low relative populations. Wyoming, Arizona, and Nevada were strong cattle states with a relatively high proportion of cattlemen to farmers, whereas the remaining states had a larger proportion of farmers to cattlemen.

With respect to the model, the implications for violence in Wyoming are clear. Larger relative populations led to the expected outcome of violence favoring ranchers in the southern portion of the state, and lower relative populations led to an uncertain expected outcome in the northeast. In the south, the reaction function for cattlemen shifted outwards, but inwards for homesteaders. In the northeast, lower relative populations shifted the reaction function for homesteaders outward and that of ranchers inwards. As long as the homesteaders' shift dominates the ranchers' shift, both $s$ and $v$ will increase with lower relative populations leading to a higher probability of violence, whereas the opposite is true with higher levels of $n$.

\footnotetext{
${ }^{45}$ The 1890 Census classified cattlemen as individuals engaged as stock raisers, herders, and drovers while farmers are individuals who are farmers, planters, and overseers. The correlation coefficient between percentage crops and relative population is -0.927 and the coefficient of correlation is -0.7944 , indicating a strong negative linear dependence between the two. The prediction equation is $Y=1.493-0.13802(X)$ with an adjusted $R^{2}$ of 0.861 .
} 
TABLE 5

COUNTY CHARACTERISTICS, 1890

\begin{tabular}{lccccc}
\hline \hline \multicolumn{1}{c}{ County } & Population & $\begin{array}{c}\text { Average } \\
\text { Farm Size }\end{array}$ & $\begin{array}{c}\text { Total Farm } \\
\text { Acres }\end{array}$ & $\begin{array}{c}\text { Percentage of } \\
\text { Farm Acres in } \\
\text { Cereal Grains }\end{array}$ & $\begin{array}{c}\text { Predicted } \\
\text { Relative } \\
\text { Population }\end{array}$ \\
\hline Crook & 2,338 & 236 & 127,245 & 2.93 & 1.09 \\
Johnson & 2,357 & 403 & 123,594 & 2.89 & 1.09 \\
Sheridan & 1,972 & 350 & 124,749 & 4.07 & 0.93 \\
Albany & 8,865 & 1,635 & 214,955 & 0.19 & 1.47 \\
Carbon & 6,857 & 452 & 133,241 & 1.11 & 1.34 \\
Converse & 2,738 & 916 & 45,400 & 1.38 & 1.30 \\
Fremont & 2,463 & 263 & 96,273 & 3.23 & 1.05 \\
Laramie & 16,777 & 1,912 & 774,161 & 0.27 & 1.46 \\
Natrona & 1,094 & 292 & 48,107 & 0.11 & 1.48 \\
Sweetwater & 4,941 & 207 & 4,757 & 0.55 & 1.42 \\
Unita & 7,881 & 362 & 130,330 & 0.46 & 1.43 \\
Weston & 2,422 & 811 & 7,470 & 0.54 & 1.42 \\
State Wide & 60,705 & 586 & $1,830,282$ & 1.14 & 1.34 \\
\hline Source: Pop & & &
\end{tabular}

Source: Population is from the 1890 Census: Statistics of Population, table 4, p. 46.

As seen from Table 5, Crook, Johnson, and Sheridan counties, comprising the northeast portion of the state, had relative populations around one indicating a relatively equal distribution of cattlemen and homesteaders. This is consistent with Frank Canton's assessment that grangers comprised a majority of Johnson County. ${ }^{46}$ However, the remaining counties had relative populations in excess of one indicating the relative strength of cattlemen. Based upon the relative populations, both ranchers and homesteaders in the northeast portion of the state increased their optimal level of $s$ and $v$. This increase led to an increased probability of violence in the region. Moreover, the relative populations were such that farmers and ranchers could form reasonable expectations that they would prevail in any violent confrontation. The evidence presented in Table 5 sheds light on why the level of organized violence occurred in this region and not in other portions of the state. Cattlemen dominated other areas, but their relative strength was less in this area.

\section{CONCLUSION}

For decades, historians and popular culture depicted the development of the American West as one of almost continual violence, a lawless domain where guns and lynching solved disputes. Recent literature has challenged this characterization arguing that the region was neither

\footnotetext{
${ }^{46}$ Quoted in Larson, History, p. 188.
} 
"lawless" nor as violent as depicted. What is more, the violence that did occur was relatively rare and predictable. This article supports this view by arguing that the Johnson County War, the seminal event between whites, that Baber describes as a transition point between the old and new West was not the outcome of irrational vigilantism as popularly portrayed. Rather it was the direct result of decisions made by rational utility maximizing individuals under conditions of uncertainty.

The "war," such as it was, was ultimately the result of incompatible property rights systems competing for the same land. Ranchers established an economic system based upon usufruct rights to land and private rights to cattle complete with an institutional structure for the protection of these rights. However, the federal government never recognized ranchers' claims on the public domain. Moreover, the federal government actively encouraged small-scale settlement of the West through various land policies that were well suited for the humid regions of America, but not the arid regions of the west. This conflict between two property rights systems culminated in the Johnson County War in Wyoming during the late nineteenth century. Using a model that specifies the conditions for violence, we demonstrate that every parameter affecting the probability of a dispute resulting in violence shifted in a manner that increased that probability of violence. As such, this article supports the argument that the level of organized violence reached in the Johnson County War was predictable and, furthermore, why this level of organized violence in the West was a relatively rare choice for resolving disputes.

\section{Appendix}

To determine the slopes of the reaction functions, we differentiated the first order conditions with respect each variable of the model and solved for the respective partial derivatives. Equations 7 and 8 represent the reaction functions.

$$
\begin{aligned}
& \frac{\partial s}{\partial v}=\frac{\beta_{v} \theta_{s} L}{(1-\beta) \theta_{s s} L-C_{s s}} \leq 0 \\
& \frac{\partial v}{\partial s}=-\left[\frac{\beta_{v} \theta_{s} L}{\beta_{v v} \theta L-C_{v v}}\right] \geq 0
\end{aligned}
$$

The slope of the homesteader's reaction function with respect to changes in $\mathrm{v}$ is negative while the slope of the rancher's function with respect to $s$ is positive. The numerator of the homesteader's function is positive while the denominator is negative due to the second order condition for maximization. Using the same logic, the slope of the rancher's function is positive. In other words, homesteader's respond negatively to any 
increase in efforts by ranchers while ranchers respond positively to increases in effort by homesteaders for any given set of exogenous variables.

To analyze the impact of each exogenous variable on the optimal level of $s$ and $v$, we differentiated the reaction functions with respect to each exogenous variable. What differentiates our application from that of Alston et al. is the modeling of the probability of an eviction as a function of the relative population $n$. Equation 9 represents the derivative of the rancher's reaction function, and equation 10 that of the homesteader's with respect to $n$.

$$
\begin{aligned}
& \frac{d V}{d N}=-\left[\frac{\beta_{v n} \theta_{s} L\left(\beta_{v v} \theta L-C_{v v}\right)-\beta_{v} \theta_{s} L\left(\beta_{v v n} \theta L\right)}{\left(\beta_{v v} \theta L-C_{v v}\right)^{2}}\right] \geq 0 \\
& \frac{d S}{d N}=\frac{\beta_{v n} \theta_{s} L\left[(1-\beta) \theta_{s s} L-C_{s s}\right]-\beta_{v} \theta_{s} L\left(-\beta_{n} \theta_{s s} L\right)}{\left.\left[(1-\beta) \theta_{s s} L-C_{s s}\right)\right]^{2}} \leq 0
\end{aligned}
$$

One can demonstrate that the sign of equation 9 is positive while that of equation 10 is negative. Increases in the relative population shifts rancher's reaction function to the right, but simultaneously shifts the homesteader's function to the left.

Without additional structure imposed upon the model, the impact on the optimal level of $v$ is indeterminant. To demonstrate this ambiguity, refer to Figure 1. Initially, the model is in equilibrium with rancher's supply $v_{0}$ and homesteader's supplying $s_{0}$ given a fixed level of $n$. Suppose that $n$ increases. The reaction function of ranchers shifts to the right, holding $s$ constant. Ranchers respond by supplying $v_{1}$. Homesteaders respond to the increase in $v$ by moving down their reaction function and supply less $s$. However, an increase in $n$ shifts homesteaders reaction function to the left. The result is an unambiguous decline in the optimal supply of $s$, but an ambiguous change in the optimal supply of $v$. If one assumes, which we do, that the shift of the homesteader's reaction function dominates that of the rancher's, then the result will be a decline in both $s$ and $v$.

\section{REFERENCES}

Allen, Douglas W. "Homesteading and Property Rights: or, How the West Was Really Won." Journal of Law and Economics 34, n. 1 (April 1991): 1-23.

Alston, Lee J, Gary D. Libecap, and Bernardo Mueller. "A Model of Rural Conflict: Violence and Land Reform Policy in Brazil." Environmental and Development Economics 4 (1999): 135-60.

. "Land Reform Policies, the Sources of Violent Conflict, and Implications for Deforestation in the Brazilian Amazon." Journal of Environmental Economics and Management 39 (2000): 162-88.

Anderson, Terry, and J. Bishop Grewell. "Property Rights Solutions for the Global Commons: Bottom-UP or Top-Down?” Duke Environmental Law and Policy Forum 10, no. 1 (Fall 1999): 73-101.

Anderson, Terry, and Peter J. Hill. "The Evolution of Property Rights: A Study of the American West." Journal of Law and Economics 18, no. 1 (April 1975): 163-79.

. "The Race for Property Rights." Journal of Law and Economics 33 (April 1991): 177-97.

. The Not So Wild, Wild West: Property Rights on the Frontier. Stanford, CA: Stanford University Press, 2004. 
Anderson, Terry, and Fred S. McChesney. "Raid or Trade? An Economic Model of Indian-White Relations." Journal of Law and Economics 37, no. 1 (April 1994): $39-74$.

Baber, William Walker. The Longest Rope; The Truth About the Johnson County War. Caldwell, ID: Caxton Printers, 1940.

Brown, Richard Maxwell. Strain of Violence: Historical Studies of American Violence and Vigilantism. New York: Oxford University Printing Press, 1975.

Bureau of Land Management. Land Patent Records Online Database.

Burroughs, John Rolfe. Guardian of the Grassland: The First Hundred Years of the Wyoming Stock Growers Association. Cheyenne, WY: Pioneer Printing \& Stationary Company, 1971.

Clawson, Marion. Uncle Sam's Acres. New York: Dodd, Mead, 1951.

Dennen, Rodgers Taylor, From Common to Private Property: The Enclosure of the Open Range. Unpublished Dissertation, University of Washington, 1975.

DeSoto, Hernando. The Mystery of Capital: Why Capitalism Triumphs in the West and Fails Everywhere Else. New York: Basic Books, 2000.

Eaton, James Winton. "The Wyoming Stock Growers Association: An Application of Davis' and North's Theory of Institutional Change." Unpublished dissertation. University of Missouri-Columbia, 1981.

Ellickson, Robert C. Order Without Law: How Neighbors Settle Disputes. Cambridge, MA: Harvard University Press, 1991.

Gates, Paul Wallace. "The Homestead Law In An Incongruous Land System." The American Historical Review 41, no. 4 (July 1936): 652-81.

Hibbard, Benjamin Horace. A History of the Public Land Policies. New York, NY: Peter Smith, 1939

Hollon, W. Eugene. Frontier Violence: Another Look. New York, 1974.

Jackson, W. Turrentine. "The Wyoming Stock Growers' Association Political Power In Wyoming Territory, 1873-1890." The Mississippi Valley Historical Review 33, no. 4. (March 1947): 571-94.

Larson, Taft Alfred. History of Wyoming. Lincoln: University of Nebraska Press, 1990.

Libecap, Gary. Locking Up the Range Federal Land Controls and Grazing. Pacific Studies in Public Policy, Ballinger Publishing Company. Cambridge, MA: Ballinger Publishing Co., 1981

Mondy, R. W. "Analysis of Frontier Social Instability." The Southwestern Social Science Quarterly 24 (1943): 167-77.

Marshall, Thomas M. "The Miners' Laws of Colorado." American Historical Review 25 (1910-1920): 426-39.

National Agricultural Statistics Service. http//www.nass.gov/QuickStats/

Osgood, Ernest Staples. The Day of the Cattleman. Minneapolis: The University of Minnesota Press, 1929.

Powell, John Wesley. Report on the Lands of the Arid Region of the United States: With a More Detailed Account of the Lands of Utah. Cambridge, MA: The Belknap Press of Harvard University Press, 1962.

Sandoz, Mari. The Cattlemen. New York: Hastings House, 1958.

Smith, Helena Huntington. The War on Powder River. New York: McGraw-Hill, 1966.

U.S. Census Bureau. Report on Agriculture by Irrigation in the Western Part of the United States at the Eleventh Census. Washington, DC: GPO, 1894. . Special Census Report on the Occupations of the United States at the Elev- 
enth Census. Washington, DC: GPO, 1896.

. Statistical Abstract of the United States, 1900, no. 23. Washington, DC: GPO, 1900.

Webb, Walter Prescott. The Great Plains. Lincoln: University of Nebraska Press, 1981.

Wyoming Stock Growers Association. By-Laws and Reports of the Wyoming Stock Growers Association, and the Laws of Wyoming for the Protection of Stock Growers as Amended by the Eighth Assembly. Cheyenne, WY: Bristol \& Knabe, 1884. 